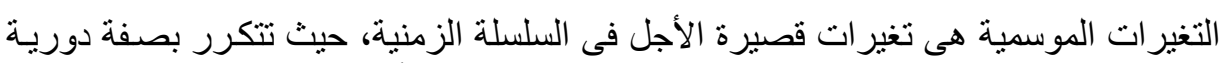

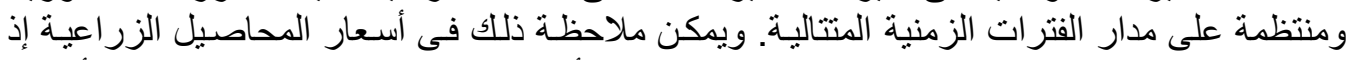

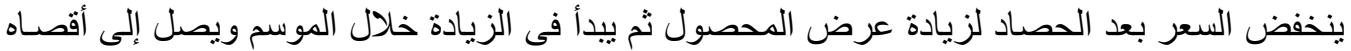

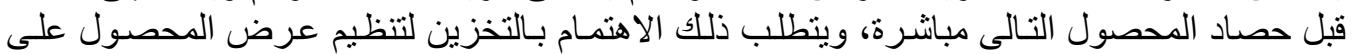

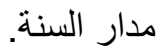

وقد تتشأ التقلبات الموسمية نتيجة اختلاف تكاليف الإنتاج على مدار السنة، ويعنى ذلك أن لكل

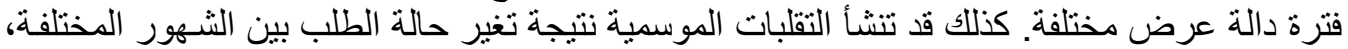

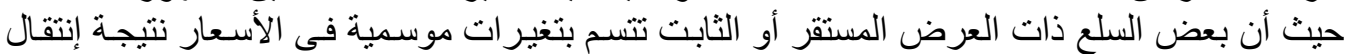

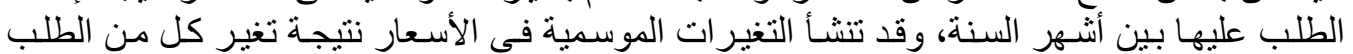
و العرض على مدار السنة.

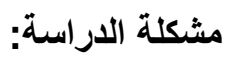

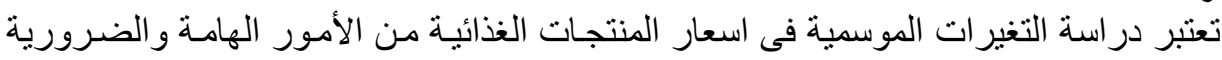

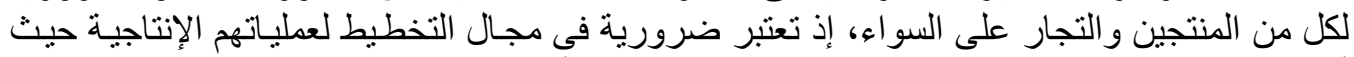

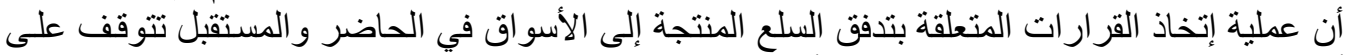

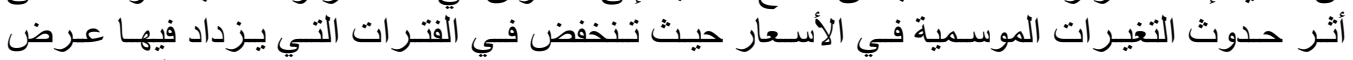

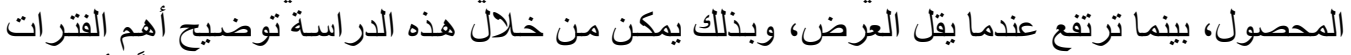

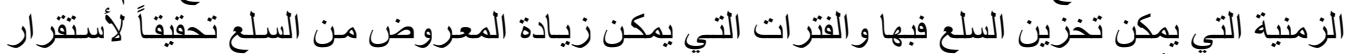
الأسعار وبعيداً عن التقلبات السعرية.

تهدف الدراسة إلى التعرف على تأثثير التغيرات الموسمية على أسعار بعض المناف المنتجات الغذائية

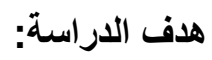

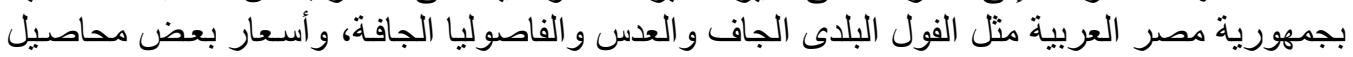

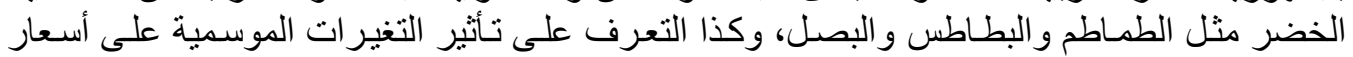

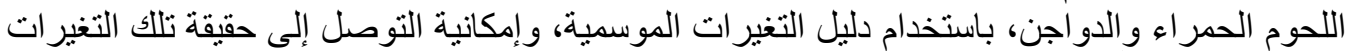
ومن ثم يمكن و فقاً لاليل التغير ات الموسمية تخطبط وتعديل السياسات التسويقية لهذه المنتجات الغذائية.

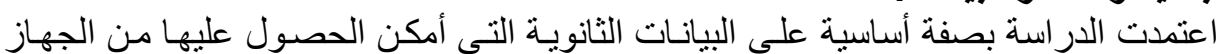
الطريقة البحثية ومصادر البيانات:

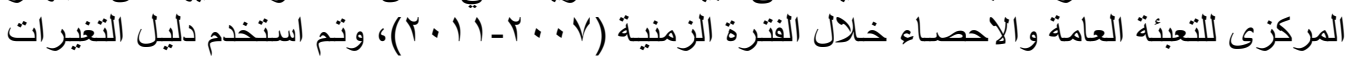

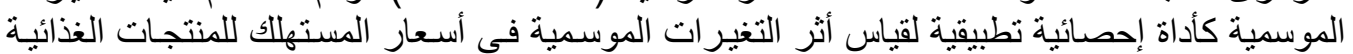

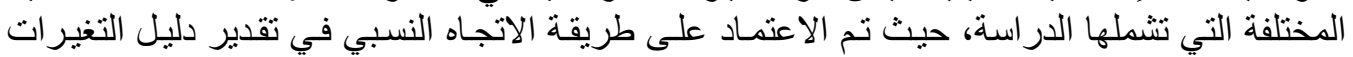

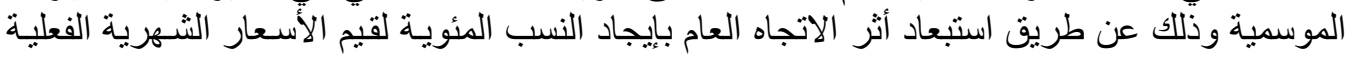

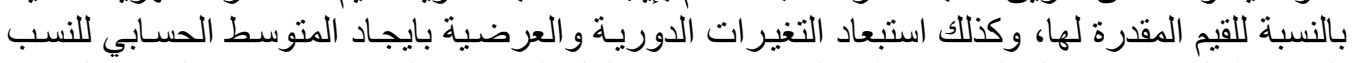

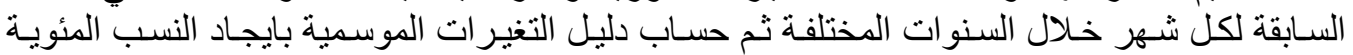
للمتوسط الحسابي لكل شهر إلى منوسط تللك المتوسطات الحسابية والتي يعبر عنها بتأثنير الموسم فقط. 
10

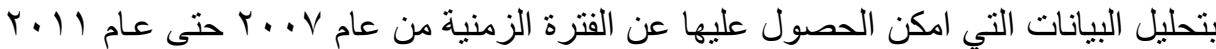
أمكن الحصول على المؤشرات آت والتنائج التالية:

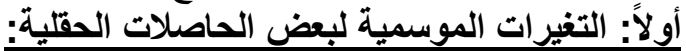

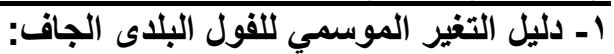

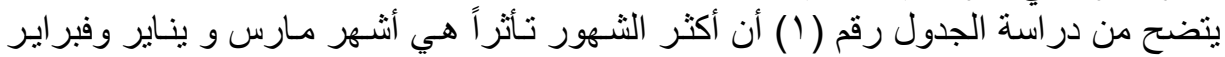

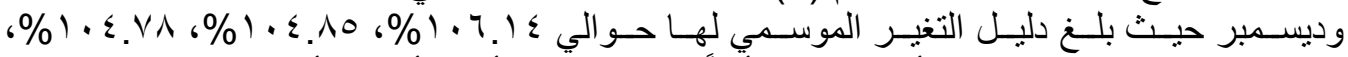

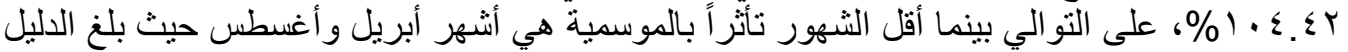

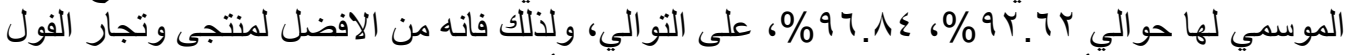

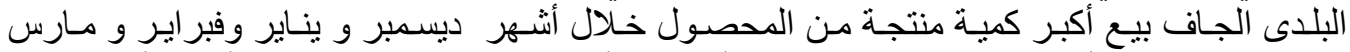

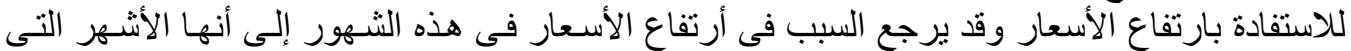

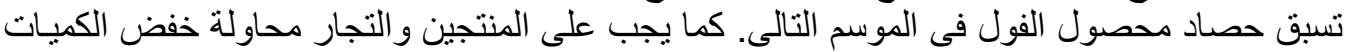

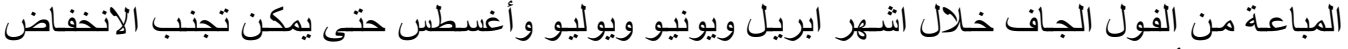
الثديد في الأسعار في هذه الثهور مع تخزين المحصول إذا سمحت تكاليف التخزين بذلك.

جدول (1): دليل التغيرات الموسمية لأسعار الفول البلاى الجاف بمصر خلال الفترة من (V . . . - .

$(r \cdot 1)$

\begin{tabular}{|c|c|c|c|c|c|c|c|c|}
\hline دليل التغيرات & المتوسط & المجموع & $r .11$ & $r .1$. & $r . . q$ & $r . \Lambda$ & $r \ldots v$ & الشهور \\
\hline 104.85 & 105.23 & 526.13 & 108.96 & 86.87 & 114.60 & $r 110.4$ & 105.28 & يناير \\
\hline 104.78 & 105.16 & 525.79 & 111.84 & 85.80 & 112.51 & 110.77 & 104.87 & فبراير \\
\hline 106.14 & 106.52 & 532.62 & 118.05 & 84.75 & 118.37 & 108.86 & 102.59 & مارس \\
\hline 92.62 & 92.95 & 464.75 & 67.34 & 83.73 & 106.27 & 107.01 & 100.40 & ابريل \\
\hline 99.12 & ^99.4 & 497.38 & 111.97 & 82.73 & 99.15 & 105.23 & 98.30 & مايو \\
\hline 97.56 & 197.9 & 489.54 & 110.81 & 81.75 & 93.62 & 105.88 & 97.48 & يونيو \\
\hline 97.65 & $\cdots .98$ & $\cdots .490$ & 113.38 & 80.80 & 91.76 & 105.34 & 98.72 & يوليو \\
\hline 96.84 & 97.19 & 485.96 & 112.23 & 81.54 & 88.61 & 104.81 & 98.77 & \\
\hline 97.57 & 97.92 & 489.59 & 115.32 & 80.61 & 87.44 & 105.44 & 100.78 & بتمبر \\
\hline 99.46 & 99.82 & 499.11 & 117.76 & 89.81 & 86.49 & 106.72 & 98.33 & اكتوبر \\
\hline 98.93 & 99.29 & 496.43 & 116.61 & 88.81 & 81.66 & 107.74 & 101.61 & نوفمبر \\
\hline 104.42 & 104.80 & $\cdots .524$ & 115.48 & 95.49 & 87.97 & 112.63 & 112.43 & سمبر \\
\hline
\end{tabular}

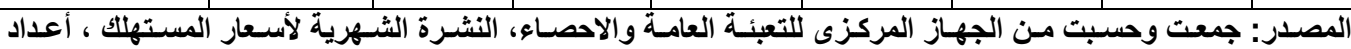

مختلفة.

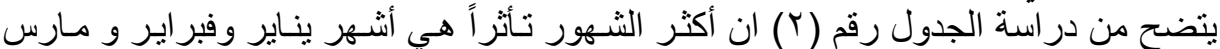

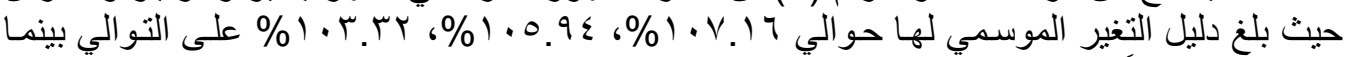

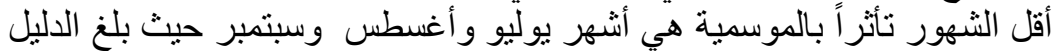

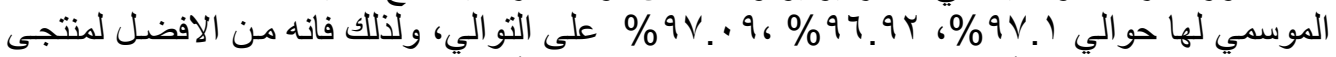

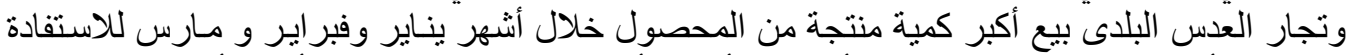

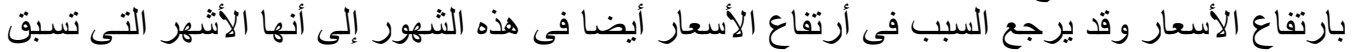

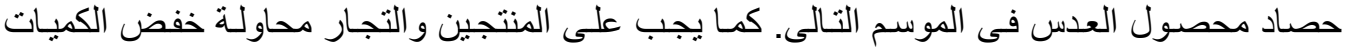

Fayoum J. Agric. Res. \& Dev., Vol. 26, No.2, July, 2012 
17

المباعـة مـن العـس خـلال اثـهر يوليو وأغسطس وسبتمبر حتى يمكن تجنب الانخفـاض الثـديد في الأسعار في هذه الثهور مع تخزين المحصول إذا سمحت تكاليف التخزين بذلك.

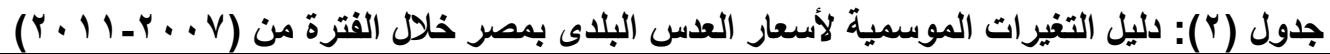

\begin{tabular}{|c|c|c|c|c|c|c|c|c|}
\hline التيل التفيزية & المتوسط & المجموع & $r+11$ & $r .1$. & $r \ldots q$ & $r \ldots \Lambda$ & $r \ldots v$ & الثهور \\
\hline 107.16 & 107.01 & 535.03 & 99.23 & 122.03 & 125.07 & 91.69 & 97.01 & يناير \\
\hline 105.94 & 105.79 & 528.94 & 98.09 & 120.76 & 122.18 & 92.32 & 95.59 & فبراير \\
\hline 103.32 & 103.18 & 515.9 & 97.19 & 119.51 & 114.11 & 91.06 & 94.03 & مارس \\
\hline 100.60 & 100.46 & 502.31 & 93.64 & 106.30 & 120.03 & 89.83 & 92.51 & ابريل \\
\hline 98.84 & 98.70 & 493.51 & 92.80 & 105.22 & 115.81 & 88.64 & 91.04 & مايو \\
\hline 97.96 & 97.82 & 489.12 & 91.97 & 98.29 & 119.57 & 89.48 & 89.81 & يونيو \\
\hline 97.086 & 96.95 & 484.75 & 91.47 & 97.32 & 118.23 & 89.31 & 88.42 & يوليو \\
\hline 96.92 & 96.79 & 483.93 & 90.66 & 101.09 & 112.74 & 89.15 & 90.29 & أغسطس \\
\hline 97.09 & 96.95 & 484.77 & 89.88 & 100.11 & 111.50 & 89.95 & 93.33 & سبتمبر \\
\hline 98.40 & 98.26 & 491.302 & 89.10 & 102.092 & 114.25 & 91.31 & 94.55 & اكتوبر \\
\hline 97.74 & 97.60 & 488.01 & 88.34 & 101.12 & 110.87 & 92.45 & 95.23 & نوفمبر \\
\hline 98.89 & 98.76 & 493.78 & 87.59 & 100.17 & 109.69 & 96.92 & 99.41 & ديسمبر \\
\hline
\end{tabular}

المصدر: جمعت وحسبت من الجهاز المركزى للتعبئة العامة والاحصاء، النشرة الثهرية لأسعار المستهلك ، أعداد مختلفة.

rـ دليل التغير الموسمي للفاصوليا البلدى الجافة:

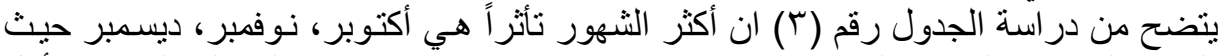

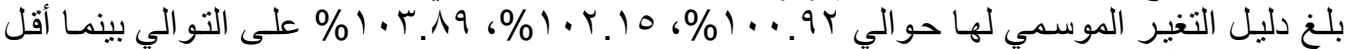

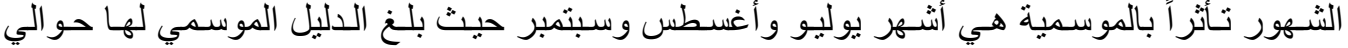

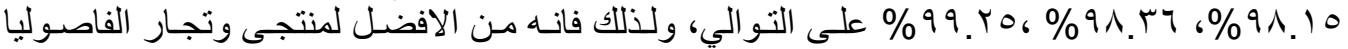

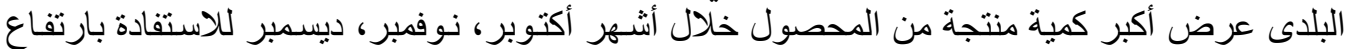

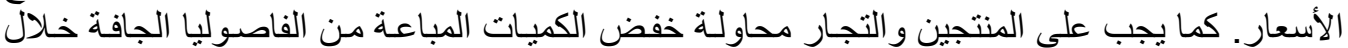

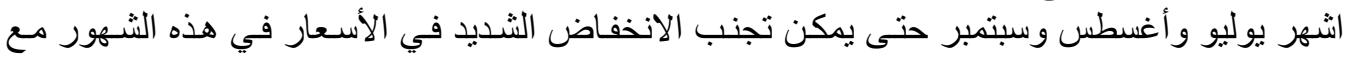

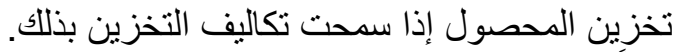

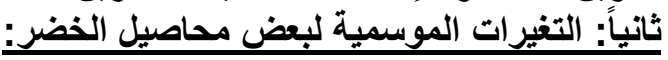

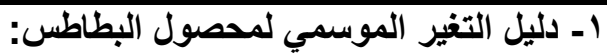

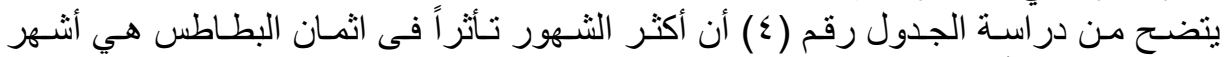

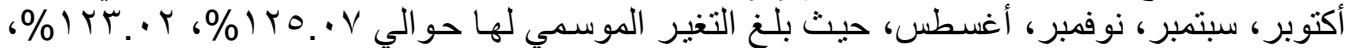

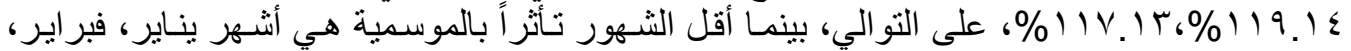

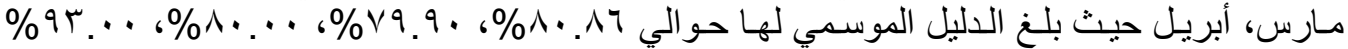

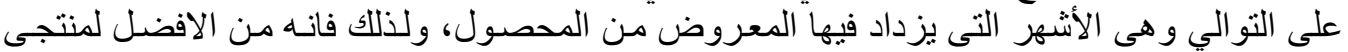

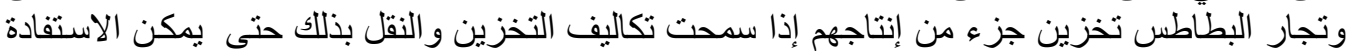

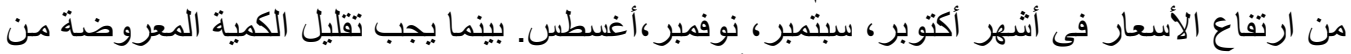

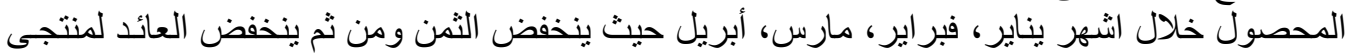
وتجار محصول البطاطس.

Fayoum J. Agric. Res. \& Dev., Vol. 26, No.2, July, 2012 
IV

\begin{tabular}{|c|c|c|c|c|c|c|c|c|}
\hline الموسمية التغيرات & المتوسط & المجموع & $r .11$ & $r \cdot 1$. & $r \ldots q$ & $r . \wedge$ & $r . r v$ & الشهور \\
\hline 97.51 & 97.51 & 487.54 & 98.32 & 98.55 & 99.78 & 103.39 & 87.5 & يناير \\
\hline $100.4^{\circ}$ & 100.45 & 502.24 & 97.88 & 98.09 & 114.06 & 105.02 & 87.19 & فبر اير \\
\hline 100.71 & 100.71 & 503.57 & 97.45 & 97.64 & 117.29 & 104.48 & 86.71 & مارس \\
\hline 99.48 & 99.48 & 497.4 & 97.03 & 97.19 & 111.06 & 103.93 & 88.19 & ابريل \\
\hline 99.31 & 99.31 & 496.53 & 96.61 & 96.75 & 110.83 & 103.40 & 88.94 & مايو \\
\hline 99.80 & 99.80 & 499.02 & 99.68 & 96.30 & 108.12 & 105.23 & 89.69 & يونيو \\
\hline 98.15 & 98.15 & 490.77 & 99.25 & 95.87 & 100.93 & 105.87 & 88.85 & يوليو \\
\hline 98.36 & 98.36 & 491.79 & 98.82 & 96.89 & 97.36 & 106.51 & 92.21 & أغسطس \\
\hline 99.25 & 99.25 & 496.27 & 98.40 & 96.45 & 96.90 & 108.30 & 96.22 & سبتمبر \\
\hline 100.92 & 100.92 & 504.61 & 97.98 & 99.64 & 98.27 & 110.77 & 97.95 & اكتوبر \\
\hline 102.15 & 102.15 & 510.73 & 97.57 & 99.19 & 99.79 & 112.98 & 101.20 & نوفمبر \\
\hline 103.89 & 103.89 & 519.46 & 97.16 & 98.75 & 99.32 & 119.30 & 104.93 & ديسمبر \\
\hline
\end{tabular}

المصدر: جمعت وحسبت من الجهاز المركزى للتعبئة العامة والاحصاء، النشرة الشهرية لأسعار المستهلك؛،

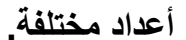

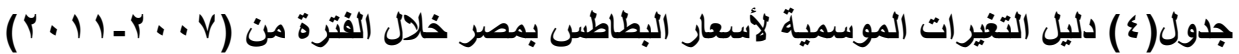

\begin{tabular}{|c|c|c|c|c|c|c|c|c|}
\hline |دليل التغيرات & المتوسط & المجموع & $r .11$ & $r .1$. & $r \ldots q$ & $r . \wedge$ & $r \ldots v$ & الشهور \\
\hline 80.86 & 81.154 & 405.77 & 89.63 & 75.77 & 71.60 & 73.99 & 94.78 & يناير \\
\hline 79.91 & 80.194 & 400.97 & 88.48 & 71.00 & 62.25 & 78.95 & 100.29 & فبر اير \\
\hline 80.01 & 80.296 & 401.48 & 94.23 & 71.57 & 62.70 & 76.61 & 96.37 & مارس \\
\hline 93.16 & 93.492 & 467.46 & 99.29 & 73.71 & 75.13 & 97.54 & 121.79 & ابريل \\
\hline 86.69 & 87.008 & 435.04 & 93.51 & 72.64 & 75.72 & 86.22 & 106.95 & مايو \\
\hline 88.38 & 88.702 & 443.51 & 92.38 & 78.11 & 72.18 & 90.01 & 110.83 & يونيو \\
\hline 111.01 & 111.412 & 557.06 & 99.11 & 92.30 & 97.06 & 121.31 & 147.28 & يوليو \\
\hline 117.13 & 117.552 & 587.76 & 110.85 & 100.66 & 102.67 & 123.76 & 149.82 & أغسطس \\
\hline 123.02 & 123.466 & 617.33 & 124.87 & 110.88 & 115.58 & 120.80 & 145.20 & سبتمبر \\
\hline 125.07 & 125.52 & 627.6 & 130.24 & 104.40 & 120.71 & 124.02 & 148.23 & اكتوبر \\
\hline 119.14 & 119.572 & 597.86 & 128.74 & 111.11 & 117.77 & 109.69 & 130.55 & نوفمبر \\
\hline 95.67 & 96.014 & 480.07 & 122.84 & 86.81 & 93.22 & 81.32 & 95.88 & سمبر \\
\hline
\end{tabular}

Fayoum J. Agric. Res. \& Dev., Vol. 26, No.2, July, 2012 
11

المصدر: جمعت وحسبت من الجهاز المركزى للتعبئة العامة والاحصـاء، النشرة الثـهرية لأسعار المستهلك ، أعداد مختلفة.

ب ـ ـ دليل التغير الموسمي لمحصول الطماطر:

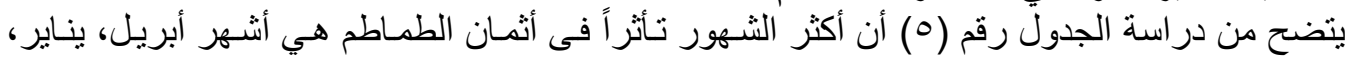

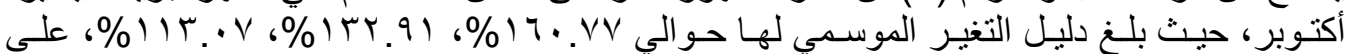

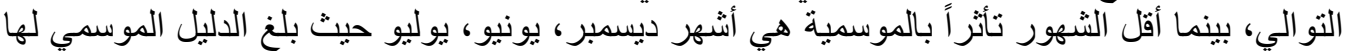

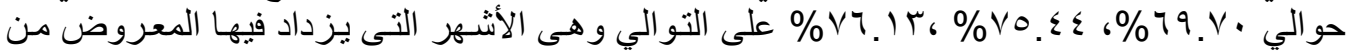

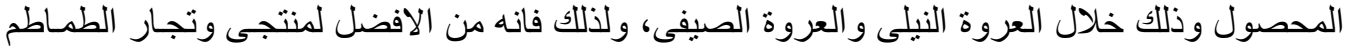

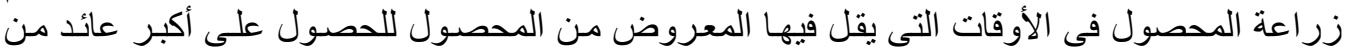

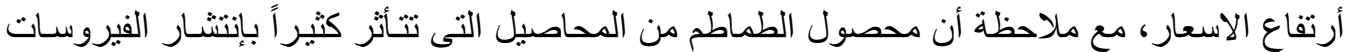

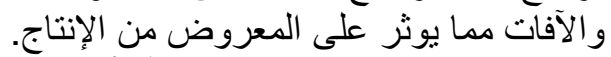

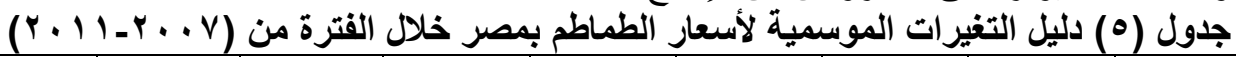

\begin{tabular}{|c|c|c|c|c|c|c|c|c|}
\hline الموسميلة التغيرات & المتوسط & المجموع & r.11 & r. 1. & r...q & $r \ldots \wedge$ & $r \ldots v$ & الشهور \\
\hline 132.91 & 139.98 & 699.91 & 63.91 & 78.16 & 76.92 & 168.22 & 312.70 & يناير \\
\hline 84.52 & 89.01 & 445.07 & 61.95 & 76.55 & 64.84 & 86.99 & 154.74 & فبراير \\
\hline 103.75 & 109.27 & 546.37 & 120.12 & 75.00 & 50.00 & 110.71 & 190.54 & مارس \\
\hline 160.77 & 169.32 & 846.61 & 144.69 & 127.57 & 173.52 & 150.52 & 250.31 & ابريل \\
\hline 103.17 & 108.66 & 543.29 & 124.64 & 80.21 & 92.63 & 94.04 & 151.76 & مايو \\
\hline 75.44 & 79.457 & 397.28 & 110.01 & 73.48 & 67.41 & 56.87 & 89.50 & يونيو \\
\hline 76.13 & 80.18 & 400.90 & 108.33 & 69.73 & 67.98 & 61.11 & 93.75 & يوليو \\
\hline 89.18 & 93.93 & 469.63 & 110.81 & 75.46 & 58.24 & 90.15 & 134.97 & أغسطس \\
\hline 104.30 & 109.84 & 549.23 & 125.34 & 114.75 & 69.04 & 97.11 & 142.99 & سبتمبر \\
\hline 113.07 & 119.08 & 595.42 & 113.41 & 165.86 & 64.62 & 103.08 & 148.44 & اكتوبر \\
\hline 86.90 & 91.62 & 458.08 & 137.96 & 94.94 & 67.6 & 65.22 & 92.37 & نوفمبر \\
\hline 69.71 & 73.42 & 367.09 & 120.52 & 62.21 & 79.84 & 43.80 & 60.73 & ديسمبر \\
\hline
\end{tabular}

المصدر: جمعت وحسبت من الجهاز المركزى للتعبئة العامة والاحصاء، النثرة الثهرية لأسعار المستهلك ، أعداد مختلفة.

بـ دليل التغير الموسمي لمحصول البصل:

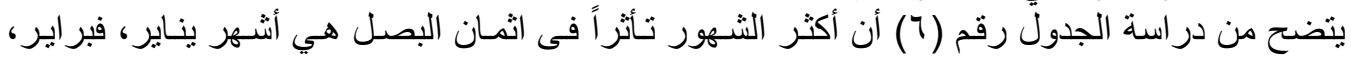

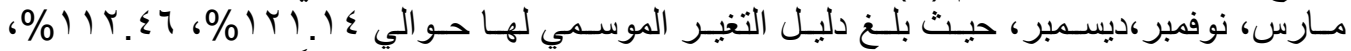

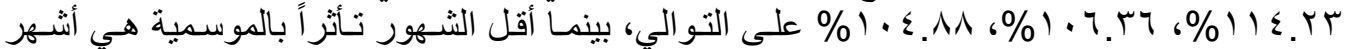

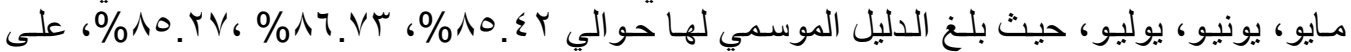

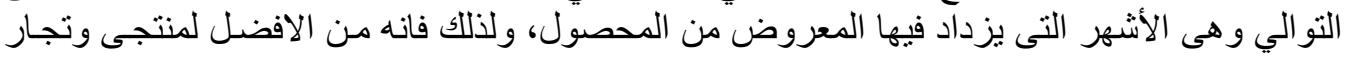

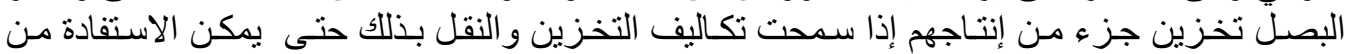

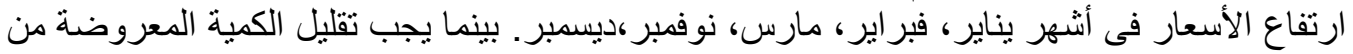

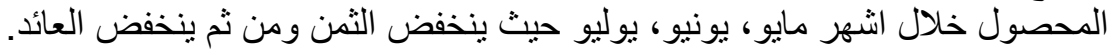

Fayoum J. Agric. Res. \& Dev., Vol. 26, No.2, July, 2012 


\begin{tabular}{|c|c|c|c|c|c|c|c|c|}
\hline | لدليل التغيرةات & المتوسط & |المجموع & $r .11$ & $r \cdot 1$. & $r \ldots q$ & $r \ldots \Lambda$ & $r \ldots v$ & الشهور \\
\hline 121.14 & 123.59 & 617.96 & 107.14 & 69.22 & 70.42 & 162.30 & 208.87 & يناير \\
\hline 112.46 & 114.73 & 573.65 & 108.45 & 73.12 & 70.84 & 141.19 & 180.05 & فبراير \\
\hline 114.23 & 116.54 & 582.69 & 110.0295 & 85.94 & 75.91 & 137.35 & 173.45 & مارس \\
\hline 103.18 & 105.26 & 526.32 & 113.89 & 89.47 & 74.55 & 110.34 & 138.06 & \\
\hline
\end{tabular}

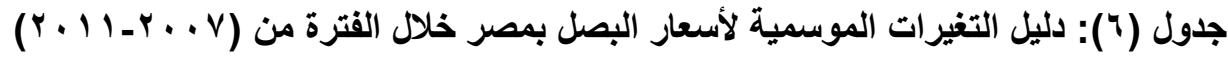

Fayoum J. Agric. Res. \& Dev., Vol. 26, No.2, July, 2012 
$r$.

\begin{tabular}{|c|c|c|c|c|c|c|c|c|}
\hline 85.42 & 87.15 & 435.74 & 112.48 & 88.17 & 57.28 & 79.36 & 98.44 & |مايو \\
\hline 86.73 & 88.48 & 442.39 & 113.95 & 86.91 & 58.30 & 82.19 & 101.03 & |يونيو \\
\hline $85+27$ & المئوسئ & 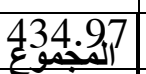 & 115,398 & $85: 69$ & $55: 33$ & $8 \rho: 44$ & 98.13 & 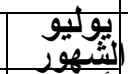 \\
\hline 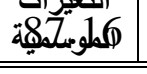 & 88.92 & 444.60 & 119.56 & 85.79 & 54.41 & 83.62 & 101.23 & \\
\hline 92.70 & 94.58 & 472.89 & 131.85 & 84.61 & 61.16 & 88.57 & 106.69 & سبتمبر \\
\hline 100.45 & 102.48 & 512.42 & 137.09 & 89.76 & 64.31 & 100.79 & 120.47 & اكتوبر \\
\hline 106.36 & 108.51 & 542.56 & 135.51 & 91.67 & 64.03 & 114.82 & 136.53 & نوفمبر \\
\hline 104.88 & 107.00 & 535.02 & 129.20 & 105.79 & 63.02 & 108.57 & 128.43 & |ديسمبر| \\
\hline
\end{tabular}

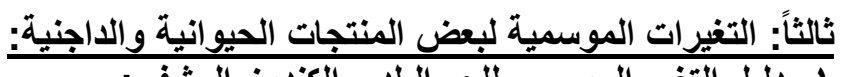

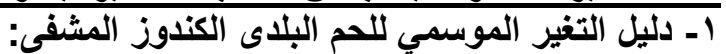

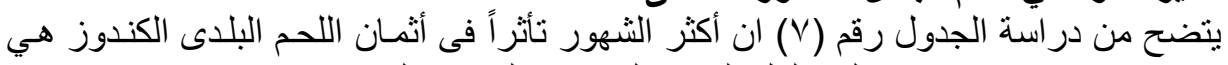

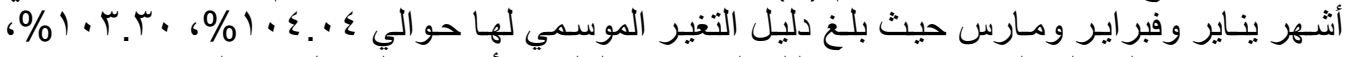

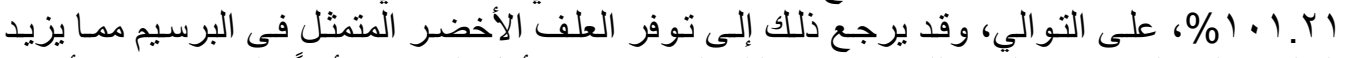

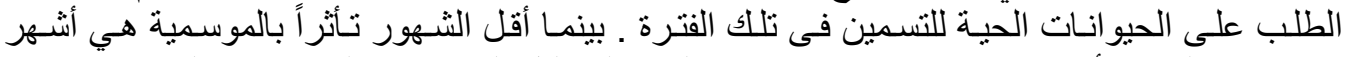

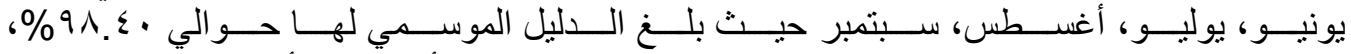

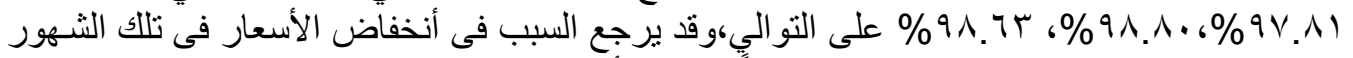

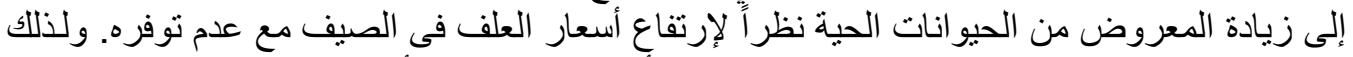

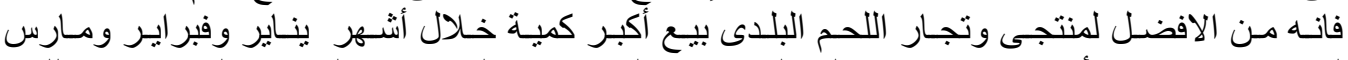

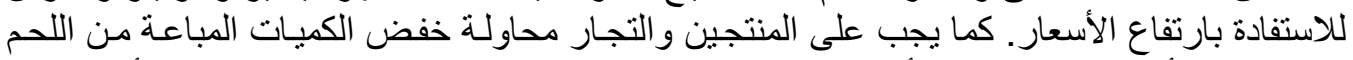
البلاى خلال أثهر يونيو، يوليو، أغسطس، سبتمبر حتى يمكن تجنب الانخفاض الثديد في الأسعار في التي هذه الثهور.

جدول (V): دليل التغيرات الموسمية لأسعار اللحم البلاى الكندوز بمصر خلال الفترة من (V . . r$(r+1)$

Fayoum J. Agric. Res. \& Dev., Vol. 26, No.2, July, 2012 


\begin{tabular}{|c|c|c|c|c|c|c|c|c|}
\hline 104.04 & 104.08 & 520.42 & 108.3424 & 97.13 & 94.44 & 103.33 & 117.17 & يناير \\
\hline 103.30 & 103.34 & 516.71 & 107.23 & 98.05 & 93.15 & 102.51 & 115.76 & فبراير \\
\hline 101.21 & 101.25 & 506.24 & 99.02 & 100.97 & 91.90 & 100.87 & 113.47 & مارس \\
\hline 101.01 & 101.05 & 505.27 & 98.91 & 105.03 & 90.59 & 99.36 & 111.37 & ابريل \\
\hline 99.19 & 99.23 & 496.17 & 97.92 & 103.84 & 89.87 & 97.85 & 106.68 & مايو \\
\hline 98.40 & 98.44 & 492.22 & 96.53 & 102.68 & 89.07 & 96.63 & 107.31 & يونيو \\
\hline 97.81 & 97.85 & 489.26 & 97.72 & 101.55 & 87.71 & 96.70 & 105.57 & يوليو \\
\hline 98.80 & 98.84 & 494.22 & 99.32 & 105.56 & 88.44 & 95.56 & 105.34 & أغسطس \\
\hline 98.63 & 98.67 & 493.34 & 100.54 & 107.85 & 89.63 & 93.80 & 101.52 & سبتمبر \\
\hline 99.27 & 99.31 & 496.57 & 101.25 & 109.94 & 90.94 & 92.86 & 101.58 & اكتوبر \\
\hline 98.86 & 98.90 & 494.49 & 101.94 & 108.78 & 91.43 & 92.06 & 100.27 & نوفمبر \\
\hline 99.47 & 99.51 & 497.56 & 100.99 & 109.48 & 95.36 & 92.93 & 98.79 & ديسمبر \\
\hline
\end{tabular}

المصدر: جمعت وحسبت من الجهاز المركزى للتعبئة العامة والاحصـاء، النشرة الثـهرية لأسعار المستهلك ، r- دليل التغير الموسمي للحم البتلو:

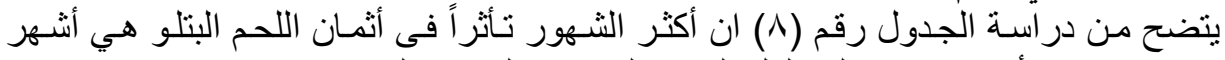

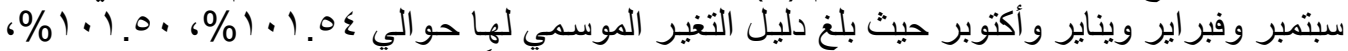

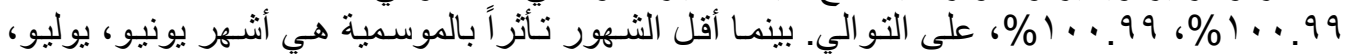

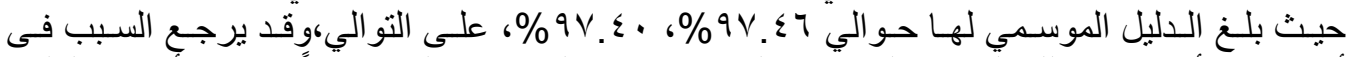

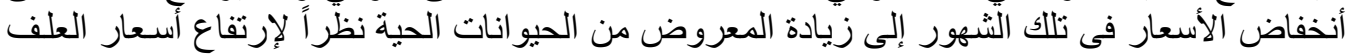

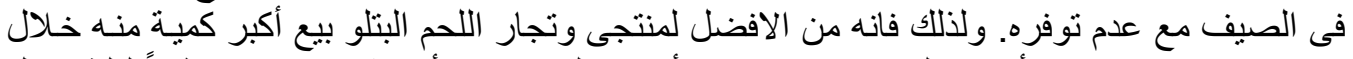

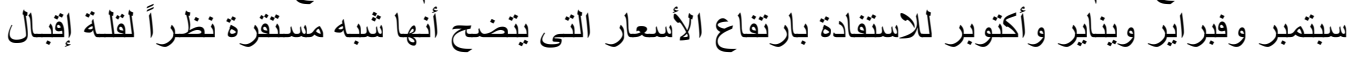
المستهلكين على البنلو. 


\begin{tabular}{|c|c|c|c|c|c|c|c|c|}
\hline \multicolumn{9}{|c|}{$\begin{array}{l}T \\
-r .\end{array}$} \\
\hline اليل التغيرة & المتوسط & المجموع & $r+11$ & $r .1$. & $r \ldots q$ & $r \ldots \wedge$ & $r \ldots v$ & الشهور \\
\hline 100.99 & 101.60 & 508.00 & 113.44 & 85.63 & 79.90 & 107.21 & 121.81 & بناير \\
\hline 101.50 & 102.10 & 510.53 & 112.27 & 86.81 & 86.23 & 105.70 & 119.52 & فبراير \\
\hline 100.64 & 101.25 & 506.24 & 103.57 & 90.10 & 93.70 & 102.89 & 115.98 & مارس \\
\hline 100.13 & 100.73 & 503.66 & 102.52 & 94.60 & 92.45 & 100.85 & 113.24 & ابريل \\
\hline 99.19 & 99.79 & 498.94 & 101.50 & 93.52 & 91.23 & 100.37 & 112.31 & مايو \\
\hline 97.46 & 98.042 & 490.21 & 100.49 & 92.47 & 90.05 & 97.98 & 109.21 & يونيو \\
\hline 97.40 & 97.99 & 489.93 & 101.32 & 95.56 & 89.09 & 96.80 & 107.16 & بوليو \\
\hline 100.35 & 100.95 & 504.74 & 102.14 & 109.62 & 88.78 & 98.62 & 105.58 & أغسطس \\
\hline 101.54 & 102.15 & 510.75 & 103.01 & 116.15 & 88.48 & 95.84 & 107.27 & سبتمبر \\
\hline 100.99 & 101.59 & 507.97 & 103.79 & 117.09 & 87.96 & 95.20 & r103.9 & اكتوبر \\
\hline 100.73 & 101.34 & 506.70 & 104.56 & 115.85 & 87.45 & 94.82 & $104.0 r$ & نوفمبر \\
\hline 99.09 & 99.69 & 498.44 & 103.58 & 114.63 & 86.40 & 92.57 & 101.25 & لديسمبر \\
\hline
\end{tabular}

المصدر: جمعت وحسبت من الجهاز المركزى للتعبئة العامة والاحصـاء، النشرة الثـهرية لأسعار المستهلك ،

أعداد مختلفة.

بـ دليل التغير الموسمي للحم الضأنى:

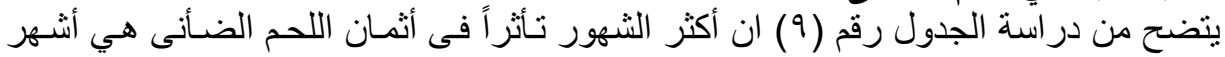

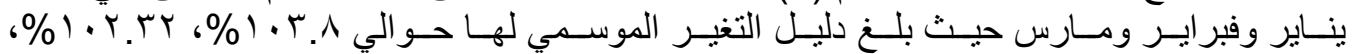

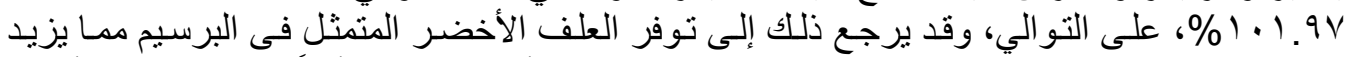

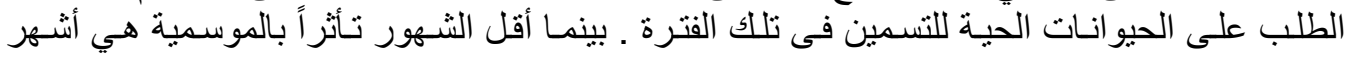

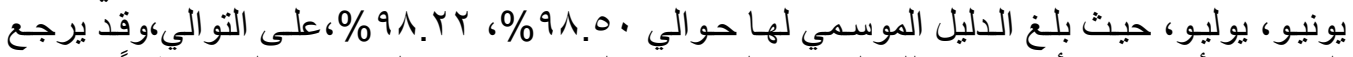

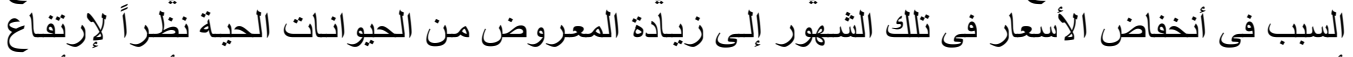

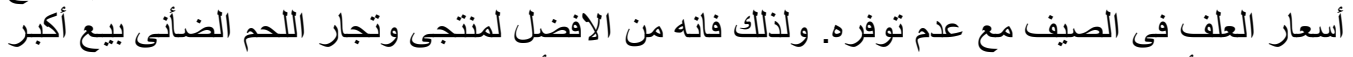

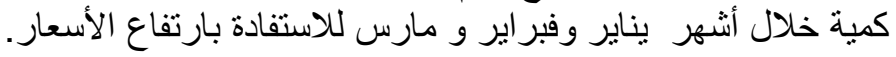

ـ ـ دليل التغير الموسمي للاجاج البلاى الهجين:

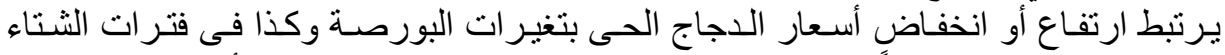

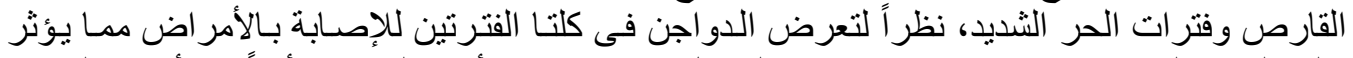

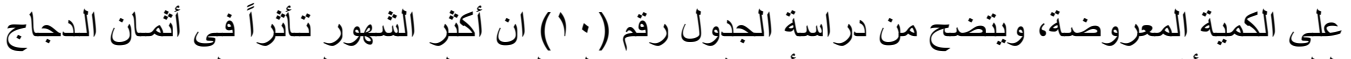

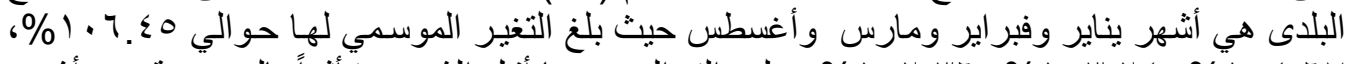

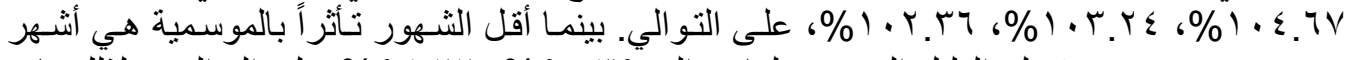

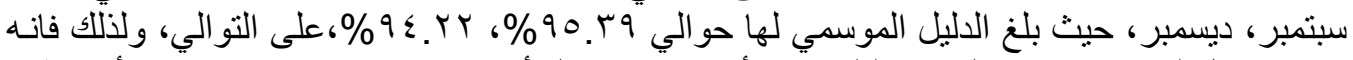

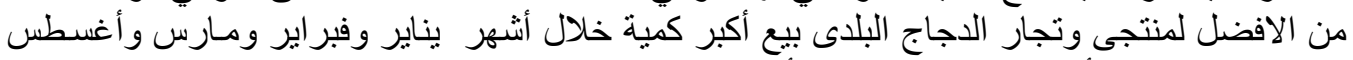

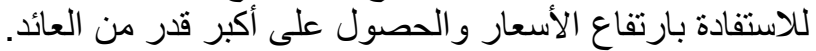

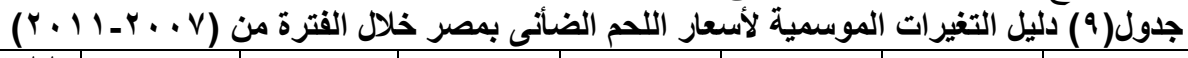

\begin{tabular}{|c|c|c|c|c|c|c|c|c|}
\hline الليل التفيرات & المتوسط & المجموع & 2011 & 2010 & 2009 & 2008 & 2007 & \\
\hline
\end{tabular}

Fayoum J. Agric. Res. \& Dev., Vol. 26, No.2, July, 2012 


\begin{tabular}{|c|c|c|c|c|c|c|c|c|}
\hline 103.80 & 103.82 & 519.10 & 108.27 & 94.23 & 98.23 & 99.40 & $118.9^{\vee}$ & بناير \\
\hline 102.32 & 102.34 & 511.71 & 107.12 & 93.08 & 97.05 & 97.90 & $116.0 \mathrm{~V}$ & فبر اير \\
\hline 101.97 & 101.99 & 509.97 & 102.44 & 96.04 & 96.16 & 102.35 & 112.97 & u \\
\hline 99.66 & 99.68 & 498.38 & 101.38 & 90.06 & 95.29 & 101.50 & 110.16 & ابريل \\
\hline 100.19 & 100.21 & 501.04 & 100.33 & 96.97 & 94.78 & 99.83 & 109.12 & \\
\hline 98.50 & 98.52 & 492.61 & 99.31 & 95.84 & 93.15 & 98.31 & 105.99 & يونيو \\
\hline 98.22 & 98.24 & 491.23 & 100.01 & 98.64 & 91.91 & 96.77 & 103.88 & يوليو \\
\hline 99.23 & 99.25 & 496.27 & 99.86 & 107.24 & 91.39 & 95.53 & 102.25 & \\
\hline 99.88 & 99.90 & 499.49 & 100.13 & 109.80 & 90.21 & 95.57 & 103.77 & سبتمبر \\
\hline 99.41 & 99.43 & 497.15 & 100.81 & 111.90 & 89.60 & 94.40 & 100.44 & اكتوبر \\
\hline 98.93 & 98.95 & 494.76 & 101.48 & 110.67 & 89.53 & 92.64 & 100.43 & نوفمبر \\
\hline 97.84 & 97.86 & 489.31 & 100.50 & 109.45 & 90.00 & 91.68 & 97.67 & ليسمبر \\
\hline
\end{tabular}

المصدر: جمعت وحسبت مـن الجهاز المركزى للتعبئة العامـة والاحصـاء، النشـرة الثـهرية لأسـعار

المستهزلك، أعداد مختلفة.

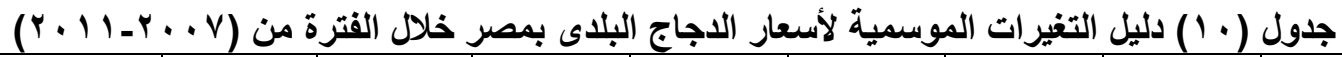

\begin{tabular}{|c|c|c|c|c|c|c|c|c|}
\hline دليل التغيرات & المتوسط & المجموع & 2011 & 2010 & 2009 & 2008 & 2007 & الشهور \\
\hline 106.45 & 106.62 & 533.09 & 101.19 & 100.32 & 103.03 & 108.97 & 119.58 & بناير \\
\hline 104.67 & 104.84 & 524.20 & 98.93 & 100.88 & 104.78 & 105.54 & 114.06 & \\
\hline 103.04 & 103.21 & 516.04 & 98.057 & 102.36 & 104.59 & 101.55 & 109.49 & مارس \\
\hline 100.38 & 100.54 & 502.69 & 99.67 & 101.35 & 103.42 & 95.49 & 102.76 & ابريل \\
\hline 99.14 & 99.30 & 496.50 & 101.53 & 103.41 & 99.79 & 92.52 & 99.25 & \\
\hline 98.80 & 98.96 & 494.82 & 99.30 & 100.48 & 102.32 & 93.09 & 99.63 & يونيو \\
\hline 98.26 & 98.41 & 492.07 & 101.13 & 107.29 & 95.48 & 91.00 & 97.17 & يوليو \\
\hline 102.36 & 102.52 & 512.62 & 102.92 & 116.64 & 97.19 & 94.79 & 101.08 & سطس \\
\hline 95.39 & 95.54 & 477.73 & 99.42 & 109.68 & 96.17 & 83.27 & 89.19 & سبتمبر \\
\hline 98.14 & 98.30 & 491.49 & 101.20 & 102.56 & 96.47 & 86.98 & 104.28 & اكتوبر \\
\hline 99.14 & 99.29 & 496.48 & 101.66 & 103.05 & 97.86 & 94.16 & 99.74 & نوفمبر \\
\hline 94.22 & 94.37 & 471.84 & 90.54 & 96.41 & 94.94 & 92.33 & 97.62 & ديسمبر \\
\hline
\end{tabular}

المصدر: جمعت وحسبت من الجهاز المركزى للتعبئة العامـة والاحصـاء، النشـرة الثـهرية لأسـعار

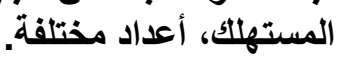

هـ دليل التغير الموسمي للاجاج الأبيض:

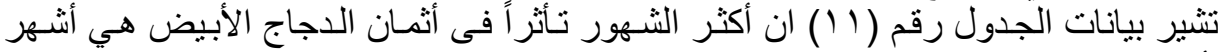

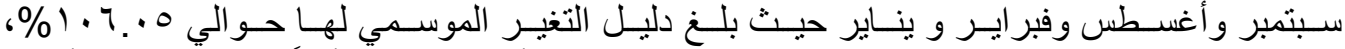

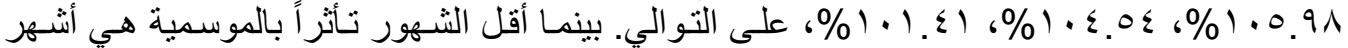

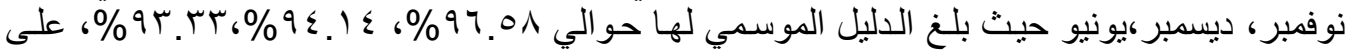

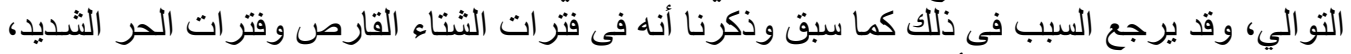

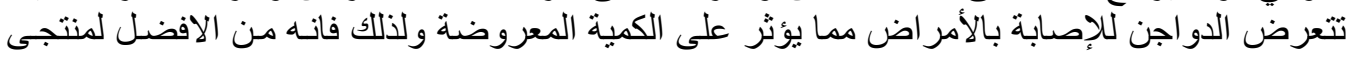

Fayoum J. Agric. Res. \& Dev., Vol. 26, No.2, July, 2012 
وتجـار الاجاج الأبيض بيع أكبر كميـة خـلال أنثـر يناير وفبر اير و أغسطس وسبتمبر للاستفادة من ارتفاع الأسعار و الحصول على الإنى أكبر قدر من العبائد.

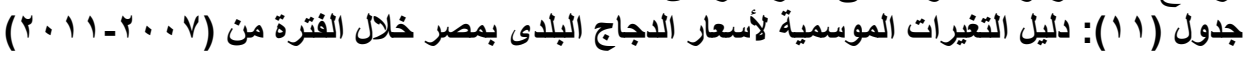
المصدر: جمعت وحسبت مـن الجهاز المركزى للتعبئة العامـة والاحصـاء، النشـرة الثـهرية لأسـعار المستهلك ، أعداد مختلفة.

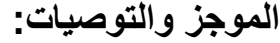

\begin{tabular}{|c|c|c|c|c|c|c|c|c|}
\hline دليل التغيرات & المتوسط & المجموع & 2011 & 2010 & 2009 & 2008 & 2007 & الشهور \\
\hline 101.41 & 102.39 & 511.98 & 109.69 & 95.77 & 92.40 & 98.36 & 115.75 & يناير \\
\hline 104.54 & 105.56 & 527.79 & 106.93 & 96.49 & 104.49 & 101.61 & 118.27 & فبراير \\
\hline 101.36 & 102.35 & 511.74 & 105.76 & 90.86 & 110.58 & 94.73 & 109.80 & مارس \\
\hline 99.07 & 100.03 & 500.18 & 106.21 & 89.74 & 108.72 & 90.79 & 104.72 & ابريل \\
\hline 97.14 & 98.09 & 490.43 & 105.08 & 99.42 & 100.00 & 86.57 & 99.36 & مايو \\
\hline 93.33 & 94.23 & 471.17 & 100.87 & 101.42 & 92.61 & 82.30 & 93.97 & يونيو \\
\hline 99.11 & 100.08 & 500.38 & 102.88 & 110.03 & 100.00 & 87.71 & 99.75 & يوليو \\
\hline 105.98 & 107.01 & 535.05 & 104.86 & 120.25 & 102.02 & 96.71 & 111.20 & أغسطس \\
\hline 106.05 & 107.08 & 535.40 & 97.77 & 111.99 & 102.55 & 104.66 & 118.42 & سبتمبر \\
\hline 101.25 & 102.23 & 511.15 & 98.57 & 104.34 & 95.44 & 100.19 & 112.61 & اكتوبر \\
\hline 96.58 & 97.52 & 487.58 & 94.64 & 104.82 & 92.32 & 92.16 & 103.63 & نوفمبر \\
\hline 94.14 & 95.05 & 475.27 & 99.53 & 97.02 & 89.36 & 89.47 & 99.89 & \\
\hline
\end{tabular}

تهدف الدراسة إلى التعرف على تأثير التغيرات الموسمية على أسعار بعض المنتجات الغذائية

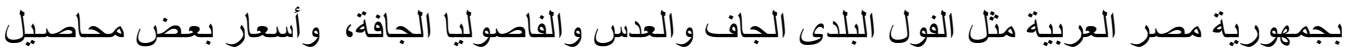

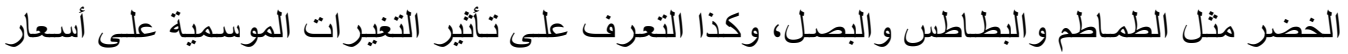

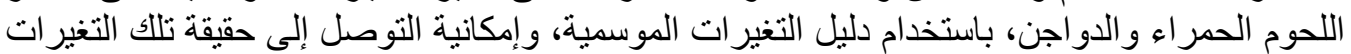

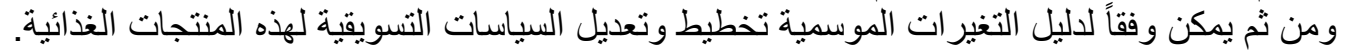

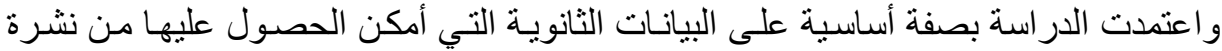

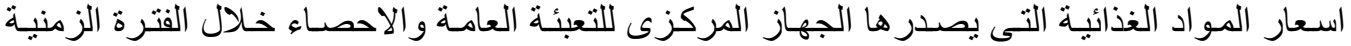

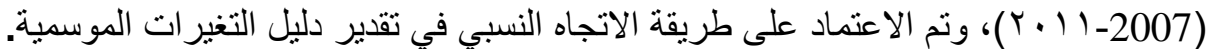
وتوصلت الدراسة إلى النتائج التالية:

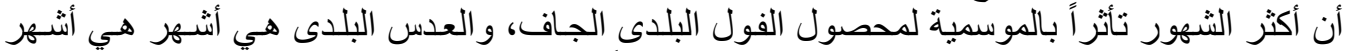

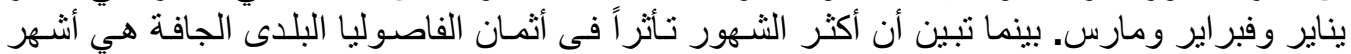

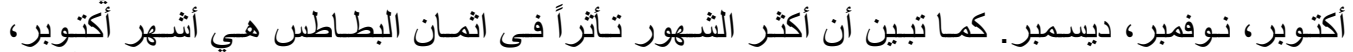

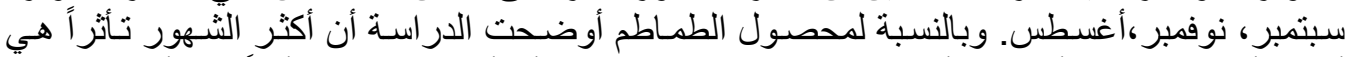

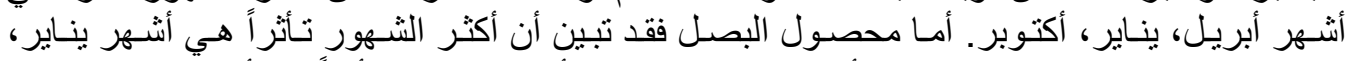

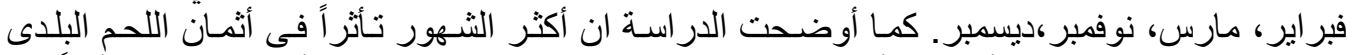

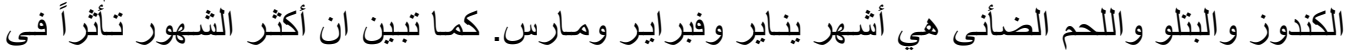
أثمان الدجاج البلدى والأبيض هي أثنهر يناير وفبراير و أغسطس وسبتمبر.

Fayoum J. Agric. Res. \& Dev., Vol. 26, No.2, July, 2012 


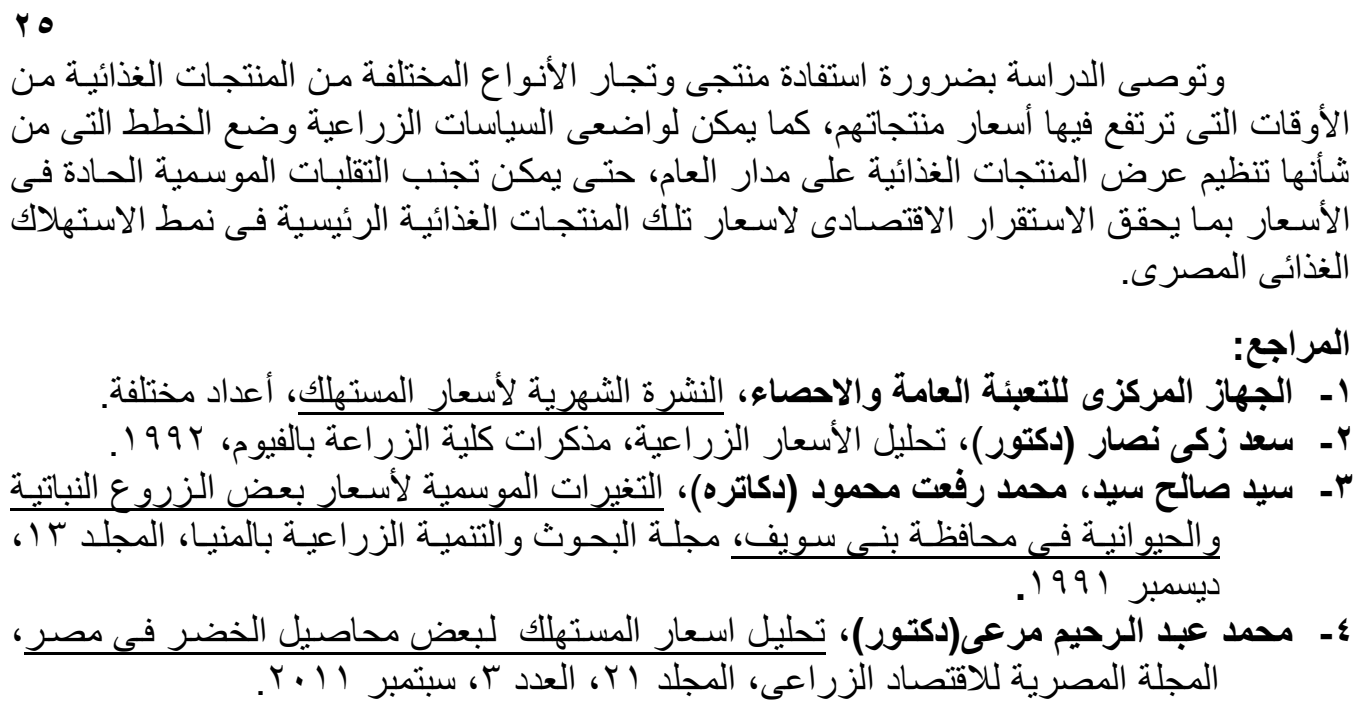

5- Box, George, Gwilym M. Jenkins and Gregory C. Reinsel "Time Series Analysis: forecasting and control" $3^{\text {rd }}$ ed, prentice-Hall Inc., New Jersey,USA, 1994.

\section{Seasonal Changes In Prices of Some Food Products in Egypt}

\section{Mohamed A. Said}

\section{Summery}

The study aimed at estimating the seasonal variations in prices of some food products in Egypt. The study showed that high effect of seasonal variations on prices of all study crops. The study has been showed also that broad beans and lentils prices increase during the month's of January, February and March. Potatoes prices increase during August, September, October and November. Onions prices increase during November, December, January, February and March. Also the result showed that red meat prices increase during the month's of January, February and March. Chicken prices increase during January, February, August and September. Therefore producers should control their supplies from these commodities in the market during these months of declined prices. 